ORIGINAL ARTICLE

\title{
Entitlement attitude in the workplace and its relationship to job satisfaction and organizational commitment
}

\author{
Sonya Asenova Dragova-Koleva \\ New Bulgarian University, Sofia, Bulgaria
}

BACKGROUND

This article is focused on the entitlement attitude in an organizational context. Its purpose was to examine the relationship of entitlement and its 3 components (active, passive and revengefulness) with job satisfaction and organizational commitment.

\section{PARTICIPANTS AND PROCEDURE}

Two independent studies were conducted to examine the discussed relationships. In study 1 and study 2 there participated respectively 110 and 95 full-time employees from both genders working in public and private organizations. The 30-item Bulgarian version of the Entitlement Questionnaire was used. Job satisfaction measurement included employees' affective response to their overall job and to various aspects of their job. The three aspects of organizational commitment (affective, instrumental and normative) were measured.

\section{RESULTS}

Active entitlement had a positive effect on satisfaction with results, satisfaction with supervisor, pay satisfaction and overall job satisfaction. It was not related to organizational commitment. Passive entitlement had a positive effect on satisfaction with tasks, but it correlated negatively with pay satisfaction. Higher level of passive entitlement predicted instrumental commitment. Revengefulness was negatively related to task satisfaction, satisfaction with supervisor and overall satisfaction, and had a negative effect on affective commitment.

CONCLUSIONS

Different forms of entitlement have a diverse influence on the various aspects of job satisfaction and components of organizational commitment. Active and passive types of entitlement are more adaptive, whereas revengefulness is a maladaptive and dysfunctional attitude.

\section{KEY WORDS}

active entitlement; passive entitlement; revengefulness; affective commitment; instrumental commitment

CORResponding Author - Sonya Asenova Dragova-Koleva, Ph.D., New Bulgarian University, J.k. Ovcha Kupel,

21 Montevideo Str., 1618 Sofia, Bulgaria, e-mail: sonyadragova@nbu.bg

AUthors' CONTRIBUtion - A: Study design - B: Data collection - C: Statistical analysis - D: Data interpretation .

E: Manuscript preparation · F: Literature search · G: Funds collection

TO CITE THIS ARTICLE - Dragova-Koleva, S. A. (2018). Entitlement attitude in the workplace and its relationship

to job satisfaction and organizational commitment. Current Issues in Personality Psychology, 6(1), 34-46.

RECEIVED 29.12.2016 · REVIEWED 01.02.2017 · ACCEPTED 21.02.2017 · PUBLISHED 12.05.2017 


\section{BACKGROUND}

Workplace entitlement is a significant organizational challenge. A large proportion of working people today demonstrate an inflated sense of self-importance and uniqueness that have formed in them expectations of special treatment, high rewards and fast career promotions provided by employers in exchange for mediocre performance (Harvey \& Dasborough, 2015). This profile of the workforce is an important concern for managers in many companies, because it raises the question how the entitled employees can be managed effectively (Tomlinson, 2013). Still there is little knowledge of the specific effects of psychological entitlement in the workplace, which is a challenge for researchers. The purpose of this study was to expand our understanding of the attitudinal outcomes of workplace entitlement, examining its relationship with job satisfaction and organizational commitment.

\section{BASIC DEFINITIONS OF ENTITLEMENT}

A number of fields have explored the concept of entitlement. In the psychological literature the main conceptualizations stemmed from clinical psychology and social psychology. From a clinical perspective psychological entitlement is a necessary component of the trait narcissism, contributing the inflated self-perceptions and excessive expectations associated with the construct (Raskin \& Terry, 1988). In social psychology Campbell, Bonacci, Shelton, Exline, and Bushman (2004) define psychological entitlement as "a stable and pervasive sense that one deserves more and is entitled to more than others" (p. 31). This definition includes a distinction between the concepts of deservingness and entitlement. A synthesis of existing definitions describes psychological entitlement as a relatively stable tendency toward highly favorable self-perceptions and a tendency to feel deserving of preferential treatment, and high levels of praise and reward, regardless of actual qualities, efforts and performance levels (Harvey \& Harris, 2010; Naumann, Minsky, \& Sturman, 2002). Entitlement is the degree to which individuals believe that they deserve the time, resources, and considerations of society (Brummel \& Parker, 2015). According to Naumann et al. (2002), entitlement often stems from social contracts, in which individuals feel entitled to certain outcomes due to their participation in a social relationship. Entitlement includes the expectation that other people and public institutions should support individual needs. In sum, psychological entitlement has been conceptualized as a personality construct influencing individuals' thoughts, attitudes and behaviors (Campbell et al., 2004; Harvey \& Martinko, 2009).
Individuals with a strong sense of entitlement are relatively self-centered, hold consistently positive views of themselves and in social settings demonstrate an inflated sense of self-importance, expecting that important events should go their way. Entitled people make efforts to maintain positive self views in the face of contradictory evidence, distorting their perceptions of reality (Martinko \& Gardner, 1987; Harvey \& Dasborough, 2015). It was found that they used self-serving attributional biases and diminished cognitive elaboration to dismiss negative feedback and treat performance failures as the fault of others rather than themselves (Harvey \& Martinko, 2009).

\section{WORKPLACE ENTITLEMENT}

The entitlement attitude affects life in different social institutions such as education, government, and family. Nowadays this phenomenon is widespread in the workplace, especially among employees from Generation Y born between 1980 and 2000 (Twenge, 2006; Laird, Harvey, \& Lancaster, 2015).

At work entitlement has been shown to manifest in unjustifiably high expectations for salary, benefits, praise, job flexibility, career plans and duties, but little willingness to take on hard work, invest resources such as time, efforts and energy, or remain loyal to the company (Harvey \& Harris, 2010). Entitled employees believe they should get exactly what they want, when they want it, regardless of the interests and well-being of others (Fisk, 2010).

Naumann et al. (2002) defined workplace entitlement perceptions as "the compensation expected as a result of an individual participating in an employment relationship" (p. 150). Their participation is a sufficient reason to deserve more than others, simply because of who they are or what they have done in the past, regardless of their actual performance.

Psychological entitlement at work can be understood and examined within the framework of equity theory and an attributional perspective to explain its effects on workplace outcomes.

\section{EQUITY THEORY AND ATTRIBUTIONAL THEORY AS A FRAMEWORK EXPLAINING WORKPLACE ENTITLEMENT}

According to equity theory, employees tend to compare what they put into the workplace (e.g. time, effort, skills, etc.) and what they receive from the employer (pay, promotions, etc). They also compare their own inputs-to-outcomes ratio to the ratio of significant others. When this ratio is perceived as unbalanced, the sense of inequity may be experienced (Adams, 1965). However, individuals differ in their sensitivity and reactions to inequity in the workplace 
(Huseman, Hatfield, \& Miles, 1987). The construct of equity sensitivity refers to individuals' degree of tolerance of inequity in the workplace (Sauley \& Bedeian, 2000). Those less sensitive are considered benevolent and do not mind receiving less for their inputs than others. Those who strive for equivalency in the perception of outcomes to inputs in relation to a comparison with others are referred to as equity sensitive. People who are very sensitive to inequity are considered entitled and actually they prefer greater rewards than their comparison with others. Entitled employees are more focused on receiving desirable outcomes than on contributing inputs and are relatively intolerant of being under-rewarded (Huseman et al., 1987).

Attributional theory suggests that entitled employees, who tend to use self-serving attributional biases, overestimate their inputs as a result of their inflated self-esteem. This cognitive exaggeration or distortion of the quantity and quality of their contribution at work provokes the perception of regular distributive and procedural injustice. Perceived injustice combined with intolerance to it leads entitled persons to operate in a perpetual state of perceived deprivation and underestimation, constantly comparing themselves with others who get more. Therefore, workplace entitlement is a product of perceptual distortion (Harvey \& Martinko, 2009).

\section{OUTCOMES OF WORKPLACE ENTITLEMENT}

Entitlement beliefs appear to play an important role in the formation and evaluation of employee expectations. The inflated self-perceptions of entitled employees cause them to form unrealistic expectations toward the job and organization. Because they expect more than they deserve objectively, often their expectations are difficult to meet. When employees with high expectations encounter a reality that is significantly less desirable, they experience "reality shock" (Wanous, Poland, Premack, \& Davis, 1992). The chronic sense of job-related frustration provokes feelings of resentment and betrayal, lack of appreciation and deprivation. Unmet expectations are associated with harmful attitudinal, behavioral and psychological outcomes that reduce organizational commitment, job satisfaction, performance, levels of trust and working relationship, life satisfaction and intention to remain (Wanous et al., 1992; Tomlinson, 2013). Workplace entitlement is related to conflicts with supervisors (Harvey \& Martinko, 2009), co-worker abuse (Harvey \& Harris, 2010), negative reactions to criticism, selfishness and lower accommodation (Campbell et al., 2004). Therefore, on the basis of psychological research it can be concluded that workplace entitlement has a predominantly negative effect on work-related variables.

\section{ENTITLEMENT AS A COMPLEX AND MULTIDIMENSIONAL PHENOMENON}

However, the interpretation of entitlement in a completely negative sense results in its oversimplified conceptualization. The nature of the entitlement construct is not only negative, as this attitude can have both positive and negative connotations. According to Fisk (2010), beliefs about what an individual feels he or she has a right to receive can be "normal", "restricted" or "excessive". Normal or legitimate entitlement assumes the idea of reciprocity and deservingness on the basis of one's human status or norms that guide decisions, as well as due to individual contributions consistent with the consequences of one's actions (Tomlinson, 2013; Fisk, 2010). Restricted entitlement refers to an individual belief that he or she doesn't deserve anything. People with restricted entitlement tend to underestimate themselves and have a reduced sense of personal value. Fisk (2010) defined excessive entitlement as a trait reflecting unjustified beliefs of deservingness.

Recently, Polish psychologists have developed a multifactorial model of entitlement (Piotrowski \& Żemojtel-Piotrowska, 2009; Żemojtel-Piotrowska et al., 2013), based on assumptions about the complex multidimensional nature of entitlement. The model postulates three forms of entitlement - active, passive and revenge entitlement - depending on the relation of self-interest to other people or institutions.

Active entitlement is based on the promotion of self-interest and self-reliance in achieving life goals. It refers to protecting one's own rights while neglecting others' interests and doing so through means of self-assertion. Active entitlement, expressed in the belief that one deserves the best, is positively related to internal locus of control, high self-esteem and agency (Piotrowski \& Żemojtel-Piotrowska, 2009). It also correlates positively with materialism and subjective well-being (Żemojtel-Piotrowska et al., 2013).

Passive entitlement is conceptualized as the belief that other people and institutions have certain obligations toward the self. For this form of entitlement, the most important aspect is that social groups to which an individual belongs must serve his/her interests. Passive entitlement is positively correlated with external locus of control, egalitarian social order, acceptance of a welfare state, a left-wing economic ideology and communion, but negatively correlated with self-esteem (Piotrowski \& ŻemojtelPiotrowska, 2009).

Revengefulness is based on the protection of self-interest in situations where other people may violate it. It may be defined as "difficulties in forgiving sustained insults" (Piotrowski \& Żemojtel-Piotrowska, 2009, p. 160) and refers to the belief that one has a right to insist on revenge after harms or insults. Revengefulness is also related to a negative vision of 
the social world including low levels of interpersonal trust and a strong belief that life represents a zero-sum game (Żemojtel-Piotrowska \& Piotrowski, 2012). It is unrelated to self-esteem and locus of control (Piotrowski \& Żemojtel-Piotrowska, 2009), but it correlates negatively with agreeableness, openness to experience, collectivism, and subjective well-being and positively with materialism (Żemojtel-Piotrowska et al., 2013).

Each of these entitlement dimensions has distinct motivational and cognitive antecedents and consequences. Obviously some aspects are maladaptive, but other forms may have positive effects. The three-dimensional model allows more precise measurement considering possible differences in linking entitlement with workplace outcomes.

\section{THE PRESENT RESEARCH: RELATIONSHIPS BETWEEN ENTITLEMENT ATTITUDES AND JOB SATISFACTION AND ORGANIZATIONAL COMMITMENT}

In the psychological literature there is little knowledge about the specific effects of the three entitlement dimensions (active, passive, revenge) in the workplace and the ways in which supervisors can effectively manage entitled employees. The purpose of the present research was to examine entitlement dimensions as predictors of job satisfaction and organizational commitment. Self-serving attributions and equity theory, mentioned above, are relevant to the current research aims, providing a framework which may explain the relationship between studied variables.

Job satisfaction is determined by employees' responses to job conditions. Job satisfaction is a workplace attitude, containing affective and cognitive components (Fisher, 2000). It is typically conceptualized as employees' affective response to their overall job or various aspects of their job such as pay, intrinsic job content, coworkers, etc. Job satisfaction reflects the person-work environment fit. Applying equity theory, it could be suggested that employees compare current job characteristics with what they would like the job to provide, what they believe they should get, and what others receive. Based on the resulting perceptions, they feel either satisfied or dissatisfied (Byrne, Miller, \& Pitts, 2010).

Organizational commitment has been conceptualized and measured in various ways. The construct represents the linkage between employee and organization that can influence the likelihood of turnover, but the nature and antecedents of that link differ. The three-component model of commitment developed by Allen and Meyer (1990) was used for conceptualization of organizational commitment. The affective component refers to the degree of identification, involvement, and emotional attachment to the employing organization. The continuance (instrumental) component refers to commitment based on the number of investments individuals make, the costs that employees associate with leaving the organization and a perceived lack of alternatives. Finally, the normative component represents employees' feelings of obligation to stay with the organization (Allen \& Meyer, 1990). Thus, organizational commitment is reflected in the employee's acceptance of the organization's goals, willingness to work hard for its interests, and the intention to remain with the organization.

Given that entitled employees use self-serving attributions, undesirable workplace events and outcomes are attributed to organizational factors and employees are likely to experience negative emotions towards the managers and the organization as a whole (Harvey \& Martinko, 2009). This attributional style of entitled individuals may promote a negative affective evaluation of the employer and the work context, reducing job satisfaction and organizational commitment.

Considering that entitlement beliefs are associated with high expectations toward other people and institutions, the relationship of entitlement with job satisfaction and organizational commitment could be explained also on the basis of studies on the met expectations and the perceived psychological contract violation. In the psychological literature unmet expectations are associated with lower job satisfaction (Wanous et al., 1992; Major, Kozlowski, Chao, \& Gardner, 1995), low levels of identification with the organization (Ashforth \& Saks, 2000) and low commitment (Wanous et al., 1992; Major et al., 1995). In this regard Naumann et al. (2002) posited that entitlement would promote low levels of job satisfaction, stemming from unmet expectations.

Expectations and beliefs regarding reciprocal obligations between the employee and the organization refer to psychological contract (Wolfe Morrison \& Robinson, 1997). When the employee perceives that the organization has failed to fulfill his/her expectations, a violation of the psychological contract occurs. The results of a survey conducted by Knights and Kennedy (2005) revealed a negative relationship between psychological contract violation and both job satisfaction $(r=-.77)$ and organizational commitment $(r=-.67)$. Given that entitled employees are less tolerant of broken promises and inequity, they are prone to job dissatisfaction and lower commitment.

Obviously the effect of entitlement on job satisfaction and organizational commitment revealed in the aforementioned research was predominately negative. Most of these studies however were interested in global perceptions of job satisfaction and organizational commitment, using overall or one-dimensional measures for both variables (Byrne et al., 2010; 
Naumann et al., 2002; Harvey \& Martinko, 2009). At the same time, previous hypotheses and results were based on a one-dimensional model of entitlement as well. All this simplified the role of entitlement in the workplace. The three constructs studied in this survey are complex and multidimensional, so it is worth examining how distinct entitlement dimensions relate to various facets of job satisfaction (i.e., work content, results, pay, supervisors, co-workers, job as a whole) and components of organizational commitment (affective, instrumental and normative). Different forms of entitlement are likely to have a diverse influence on various aspects of job satisfaction and organizational commitment. On the one hand, the negative effect of entitlement is obvious and established on the basis of unmet expectations and an attributional style, blaming others when negative outcomes occur. On the other hand, due to biased self-serving attributions, entitled employees tend to attribute desirable outcomes to internal factors, which results in formation of a favorable attitude toward themselves while believing that the organization has little responsibility for positive outcomes. Therefore, it might be supposed that some aspects of job satisfaction and organizational commitment will be predicted positively and others negatively by entitlement. In other words, distinct relationships of entitlement dimensions and aspects of job satisfaction and organizational commitment components were suggested in this research.

Two independent studies, described below, were conducted to examine the discussed relationships.

\section{PARTICIPANTS AND PROCEDURE}

\section{STUDY 1}

Study 1 aimed to examine how active, passive and revenge entitlement relate to various aspects of job satisfaction. Considering that active entitlement is associated with high self-esteem and positive self-presentation, agency and psychological well-being that will promote the sense of self-worth, on the one hand, and the feeling of insufficient appreciation, on the other hand, it could be predicted that:

Hypothesis 1 . Active entitlement will be positively related to satisfaction with tasks and results, as well as overall satisfaction, but it will correlate negatively with pay satisfaction.

In support of Hypothesis 1, Sauley and Bedeian's (2000) study also found that higher levels of entitlement were associated with lower levels of pay satisfaction.

Given that passive entitlement is based on seeing the social world as a net of obligations between individuals and public institutions with the focus on one's own group interest (Żemojtel-Piotrowska et al.,
2013) and is related to low self-esteem, external locus of control and communion, it could be supposed that employees with high passive entitlement will tend to be helpless to some extent and more dependent on other people in the organization, because they rely on them for achieving their goals. So, the following hypothesis could be formulated:

Hypothesis 2. Passive entitlement will be related positively to satisfaction with supervisor and co-workers, but negatively with task and results satisfaction.

As revengeful people find it difficult to forgive insults and negative feedback, they more often experience job-related frustration and feelings of resentment. They perceive life as a zero-sum game, manifest low interpersonal trust and believe they are deprived of something they deserve, which results in anger and negative emotions toward the workplace.

Hypothesis 3. Negative relationships are expected between revengefulness and all aspects of job satisfaction.

\section{Sample 1}

Participants of study 1 were 110 full-time employees working in a variety of organizations $(35.00 \%$ male, $75.00 \%$ female), whose ages ranged from 20 to 62 years old $(M=38.00, S D=1.28) .89 .10 \%$ of participants had higher education, and $10.90 \%$ had secondary education. Their work experience varied from 1 month to 42 years $(M=10.76, S D=10.57) .45 .40 \%$ were white-collar workers (executives), $38.20 \%$ were experts and $16.40 \%$ occupied managerial job positions. $43.60 \%$ of participants worked in public organizations, $56.40 \%$ in private companies.

\section{Measures}

Participants responded to items from two distinct measures:

1. The 30-item Bulgarian version of the Entitlement Questionnaire (Piotrowski \& Żemojtel-Piotrowska, 2009), adapted by Paspalanova and Dragova (2013), was used. It consists of three subscales active entitlement, passive entitlement, and revengefulness. Each subscale includes 10 items. Response options range from 1 (I strongly disagree) to 6 (I strongly agree). The questionnaire has proven reliability and has confirmed the three-dimensional structure of the original Polish method (Paspalanova \& Dragova, 2013).

2. Job satisfaction was measured using the Job Satisfaction Questionnaire developed by Radoslavova and Velichkov (2005). This scale combines the global approach and the aspect approach for examining job satisfaction. It consists of six subscales: the Global job satisfaction subscale with 8 items, reflecting one's attitude to the job as a whole; the Task satisfaction subscale (15 items); the Results 
satisfaction subscale (3 items); the Supervisor satisfaction subscale (18 items); the Co-workers satisfaction subscale (18 items); and the Pay satisfaction subscale (10 items). Response options range from 1 (not at all) to 6 (completely). All scales have proven reliability and validity.

\section{Demographics}

Participants also completed a demographic questionnaire indicating their age, gender, tenure, education level, job position and type of organization.

\section{STUDY 2}

Study 2 aimed to examine how active, passive and revenge entitlement relate to three aspects of organizational commitment.

Given that entitlement and its components are related to self-interest and correlate with materialism, it could be supposed that the entitled employees perceive workplace as a source of goods, status and opportunities for success. Thus, for them the organization is more likely to be just a means of achieving desired outcomes.

Hypothesis 4. A positive relationship between instrumental commitment and three facets of entitlement will be expected.

Given that entitlement is a component of the contemporary psychological contract, but nowadays this contract can be easily violated due to rapid changes and ambiguity in the organizational context, entitled employees are more likely to feel frustrated because of the perceived discrepancy between actual and desired outcomes. According to Wolfe Morrison and Robinson (1997), the violation of the psychological contract has cognitive and emotional aspects. The cognitive aspect refers to an employee's mental calculation of entitlements received relative to those promised by the organization, whereas the emotional aspect represents the feelings of betrayal, anger and resentment (Wolfe Morrison \& Robinson, 1997). Revengeful people, who have difficulties in forgiving wrongs, are especially sensitive to unmet expectations, perceiving them as an insult from the company. Hence it could be suggested that:

Hypothesis 5. Revengefulness will be related negatively to affective commitment.

The results of Campbell et al. (2004) indicated that individuals with high levels of psychological entitlement are selfish in their relationships, displaying comparatively low levels of empathy, perspective taking, and respect. Therefore, entitled employees focus mainly on receiving rather than on giving and contributing, so:

Hypothesis 6. All three entitlement dimensions will relate negatively to normative organizational commitment.
Sample 2

The sample consisted of 95 full-time employees ( $40.00 \%$ male, $60.00 \%$ female), ranging in age from 22 to 57 years old $(M=33.34, S D=1.01)$. Their work experience varied from 1 to 25 years $(M=5.00$, $S D=5.63) .86 .30 \%$ of participants had higher education, and $13.70 \%$ had secondary education. $81.10 \%$ were white-collar workers, and $18.90 \%$ occupied managerial job positions. $40.00 \%$ of participants worked in public organizations, $60.00 \%$ in private companies.

\section{Measures}

The 30-item Bulgarian version of the Entitlement Questionnaire was used in the same form as in study 1.

The three-dimensional scale of organizational commitment (Allen \& Meyer, 1990; adapted by Ilieva, 1998) consisting of 24 items was used. The questionnaire has three subscales, each with 8 items: Affective commitment; Instrumental commitment and Normative commitment. Participants answer questions on a 5-point Likert scale from 1 (absolutely disagree) to 5 (absolutely agree).

\section{Demographics}

Participants completed a demographic questionnaire in the same form as in study 1 .

\section{RESULTS}

\section{RESULTS FROM STUDY 1}

\section{Descriptive statistics and correlational analyses}

Table 1 presents means, standard deviations, reliabilities and correlations for entitlement dimensions and aspects of job satisfaction. Preliminary scatterplots revealed ten outliers that were excluded from the analyses.

Internal consistency reliability (Cronbach's $\alpha$ ) of the scales varied from acceptable $(\alpha=.75)$ to high $(\alpha=.96)$. Employees participating in study 1 showed a high level of active and passive entitlement, whereas revengefulness was moderately expressed. The mean scores for entitlement dimensions were compared by the paired-sample $t$-test and differences between them were statistically significant, $p<.001$. Participants were more satisfied with their results at work and with their tasks. They were less satisfied with pay. Results from the correlational analyses indicated that active entitlement was positively related to global satisfaction, results satisfaction and satisfaction with supervisor. Passive entitlement correlated only with task satisfaction, the relationship being positive and low. Passive form of entitlement was 
Table 1

Internal consistency reliability (Cronbach's $\alpha$ ), means, standard deviations and intercorrelations among all variables in study $1(N=100)$

\begin{tabular}{|c|c|c|c|c|c|c|c|c|c|}
\hline Variables & 1 & 2 & 3 & 4 & 5 & 6 & 7 & 8 & 9 \\
\hline $\begin{array}{l}\text { 1. Active } \\
\text { Entitlement }\end{array}$ & $(.80)$ & & & & & & & & \\
\hline $\begin{array}{l}\text { 2. Passive } \\
\text { Entitlement }\end{array}$ & $.21^{*}$ & $(.75)$ & & & & & & & \\
\hline $\begin{array}{l}\text { 3. Revenge } \\
\text { Entitlement }\end{array}$ & .06 & -.02 & $(.80)$ & & & & & & \\
\hline $\begin{array}{l}\text { 4. Task } \\
\text { Satisfaction }\end{array}$ & .15 & $.27^{*}$ & $-.28^{* *}$ & $(.95)$ & & & & & \\
\hline $\begin{array}{l}\text { 5. Results } \\
\text { Satisfaction }\end{array}$ & $.38^{* *}$ & .16 & $-.18^{\wedge}$ & $.38^{* *}$ & $(.76)$ & & & & \\
\hline $\begin{array}{l}\text { 6. Supervisor } \\
\text { Satisfaction }\end{array}$ & $.35^{* *}$ & .02 & $-.21^{*}$ & .08 & $.23^{*}$ & $(.94)$ & & & \\
\hline $\begin{array}{l}\text { 7. Co-workers } \\
\text { Satisfaction }\end{array}$ & .08 & .01 & -.08 & .15 & .11 & $.28^{* *}$ & $(.96)$ & & \\
\hline $\begin{array}{l}\text { 8. Pay } \\
\text { Satisfaction }\end{array}$ & .15 & -.18 & -.11 & .03 & .04 & $.41^{* *}$ & .14 & $(.96)$ & \\
\hline $\begin{array}{l}\text { 9. Overall } \\
\text { Satisfaction }\end{array}$ & $.22^{*}$ & -.07 & $-.35^{* *}$ & $.20^{*}$ & $.22^{*}$ & $.31^{* *}$ & $.34^{* *}$ & $.42^{* *}$ & $(.91)$ \\
\hline$M$ & 5.01 & 4.63 & 3.19 & 3.87 & 4.23 & 3.26 & 3.48 & 2.31 & 3.39 \\
\hline$S D$ & 0.53 & 0.62 & 0.74 & 0.76 & 0.67 & 0.85 & 0.83 & 1.02 & 0.92 \\
\hline
\end{tabular}

Note. ${ }^{\wedge} p<.10 .{ }^{*} p<.05 .{ }^{* *} p<.01$.

unrelated to almost all aspects of work context. The pattern of correlation between revengefulness and job satisfaction supported the assumed relationship between variables. Revenge entitlement correlated negatively with all aspects of job satisfaction except satisfaction with co-workers and pay. A higher correlation was established between revengefulness and global satisfaction $(r=-.35, p<.001)$. People who find it difficult to forgive are more dissatisfied with various aspects of their job. They have a negative attitude to their tasks, achieved results, supervisor and the job as a whole.

\section{Regression analyses}

In order to examine more complex interrelations between entitlement attitudes and job satisfaction and to answer the question whether entitlement really has negative effects on workplace outcomes, multiple hierarchical regression analyses were performed separately for each aspect of job satisfaction. To control for demographic variables, data for age, gender, work experience, education level, work position and type of company were introduced to the regression model in the first step. Controlling for demographic characteristics could ensure that the expected effect of essential predictors would be "independent" of the influence of controlled variables. In the second step, active, passive and revenge entitlement were introduced as predictors into the equation and the mean scores for job satisfaction and its aspects as dependent variables. Table 2 presents the results from regression analyses.

The first model, including demographic variables, was not a good fit to the data, $F(6,103)=0.35, p=.910$, explaining only $2 \%$ of the variance in task satisfaction. Adding entitlement dimensions as predictors in the regression model significantly increased its predictive power, $F(9,100)=2.00, p=.047$, accounting for $15.30 \%$ of variability in the dependent variable. The change of $R^{2}$ was slight, but statistically significant, $F(3,100)=5.23, p=.002$. In step 2 , task satisfaction was influenced positively by passive entitlement, $t(100)=2.29, p=.024$ and negatively by revengefulness, $t(100)=-3.06, p=.003$. From the standardized $\beta$ value and the magnitude of the t-statistics it could be seen that revengefulness had a slightly greater impact than passive entitlement.

The model of controlled demographic variables accounted for $14.30 \%$ of the variance in satisfaction with results, $F(6,93)=2.60, p=.023$. Results satisfaction was predicted by gender (higher among women), higher job position (managers) and employment 
Table 2

Summary of results of multiple hierarchical regression analyses for entitlement dimensions as predictors of job satisfaction

\begin{tabular}{|c|c|c|c|c|c|c|}
\hline $\begin{array}{l}\text { Models/ } \\
\text { variables }\end{array}$ & $\begin{array}{c}\text { Task } \\
\text { satisfaction }\end{array}$ & $\begin{array}{c}\text { Results } \\
\text { satisfaction }\end{array}$ & $\begin{array}{c}\text { Supervisor } \\
\text { satisfaction }\end{array}$ & $\begin{array}{l}\text { Co-workers } \\
\text { satisfaction }\end{array}$ & $\begin{array}{c}\text { Pay } \\
\text { satisfaction }\end{array}$ & $\begin{array}{c}\text { Overall } \\
\text { satisfaction }\end{array}$ \\
\hline Model 1 & $\Delta R^{2}=-.04$ & $\Delta R^{2}=.09^{*}$ & $\Delta R^{2}=.09^{*}$ & $\Delta R^{2}=-.04$ & $\Delta R^{2}=.23^{* * *}$ & $\Delta R^{2}=.08^{*}$ \\
\hline Gender & .01 & $.25^{*}(2.48)$ & .05 & -.10 & -.01 & .18 \\
\hline Age & -.07 & -.38 & $-.40^{\wedge}$ & -.06 & $.48^{*}(2.43)$ & .13 \\
\hline Education & -.02 & .02 & .03 & -.09 & -.03 & -.11 \\
\hline Tenure & .20 & .01 & -.01 & .17 & -.29 & -.21 \\
\hline Job position & .02 & $.33^{* *}(-2.81)$ & -.11 & -.03 & -.08 & $.24^{*}(-2.02)$ \\
\hline Org. type & .12 & $-.38^{* *}(2.84)$ & $-.25^{\wedge}$ & .02 & $.61^{* * *}(-5.05)$ & .01 \\
\hline Model 2 & $\Delta R^{2}=.08^{*}$ & $\Delta R^{2}=.20^{* * *}$ & $\Delta R^{2}=.20^{* * *}$ & $\Delta R^{2}=-.06$ & $\Delta R^{2}=.32^{* * *}$ & $\Delta R^{2}=.25^{* * *}$ \\
\hline Gender & -.05 & .19 & -.07 & -.12 & -.10 & .04 \\
\hline Age & .05 & -.33 & -.24 & -.04 & $.61^{* *}(3.15)$ & .36 \\
\hline Education & .03 & -.01 & .03 & -.10 & -.03 & -.08 \\
\hline Tenure & .10 & .02 & -.04 & .19 & -.30 & -.29 \\
\hline Job position & .02 & $.31^{* *}(-2.78)$ & -.15 & -.03 & -.11 & $.20^{\wedge}$ \\
\hline Org. type & .10 & $-.35^{* *}(2.76)$ & -.20 & .04 & $.67^{* * *}(-5.81)$ & .05 \\
\hline $\begin{array}{l}\text { Active } \\
\text { entitlement }\end{array}$ & .05 & $.32^{* * *}(3.31)$ & $.34^{* * *}(3.57)$ & .12 & $.24^{* *}(2.71)$ & $.28^{* *}(3.03)$ \\
\hline $\begin{array}{l}\text { Passive } \\
\text { entitlement }\end{array}$ & $.22^{*}(2.29)$ & .11 & -.02 & -.03 & $-.24^{* *}(-2.82)$ & -.12 \\
\hline $\begin{array}{l}\text { Revenge- } \\
\text { fulness }\end{array}$ & $-.30 * *(3.06)$ & -.01 & $-.21^{*}(-2.13)$ & .01 & $-.16^{\wedge}$ & $-.38^{* * *}(-4.05)$ \\
\hline
\end{tabular}

Note. Entries are standardized regressions coefficients, T-ratios in parentheses.

${ }^{\wedge} p<.10 .{ }^{*} p<.05 .{ }^{* *} p<.01 .{ }^{* *} p<.001$.

in a public organization. Introducing the entitlement dimensions explained an additional $12.20 \%$ of the variation in satisfaction with results. In the second step results satisfaction was predicted by active entitlement, higher job position and employment in a public organization, $F(9,90)=3.60, p=.001$. From the magnitude of the $t$-statistics it could be seen that active entitlement had a slightly greater impact than demographic variables. Results satisfaction was unrelated to passive and revenge entitlement.

Controlled demographic variables together contributed significantly to the regression model, $F(6,93)=2.52, p=.026$, and explained $14.00 \%$ of variability in satisfaction with supervisor. Including the three forms of entitlement as additional independent variables made a statistically significant contribution to predicting the outcome, $F(9,90)=3.71, p=.001$. The final model accounted for $27.00 \%$ of the variance in satisfaction with supervisor. This aspect of job satisfaction was predicted by a higher level of active entitlement and a lower level of revengefulness. The standardized $\beta$ value and the magnitude of the $t$-sta- tistics indicated that active entitlement made a greater contribution as a predictor (see Table 2).

Neither the first model (demographic variables alone), $F(6,93)=0.35, p=.911$, nor the second model (demographics plus entitlement beliefs), $F(9,90)=0.36$, $p=.951$, predicted scores in satisfaction with co-workers to a statistically significant degree.

Pay satisfaction was predicted by higher age and employment in a private organization, $F(6,93)=6.05$, $p<.001$. Demographic variables in the first step explained $28.10 \%$ of the variance in pay satisfaction. Higher level of active entitlement and lower level of passive entitlement in the second step contributed statistically significantly to predicting pay satisfaction, $F(9,90)=6.23, p<.001$. All predictors together accounted for $38.40 \%$ of variability in pay satisfaction.

Higher job position was positively related to overall job satisfaction, $F(6,93)=2.44, p=.031$. Controlled demographic variables accounted for $13.60 \%$ of the variance in global satisfaction. Active entitlement and lower level of revengefulness predicted overall job satisfaction, $F(9,90)=4.61, p<.001$. The global 
aspect was unrelated to passive entitlement. Introducing the entitlement dimensions explained an additional $18 \%$ of the variation in overall satisfaction. Revengefulness made a greater contribution as a predictor of overall satisfaction (see Table 2).

Considering that public and private companies differ in human resource management practices and degree of autonomy, a possible interaction between the type of organization (public/private) and employees' entitlement dimensions was tested in the third step of the analyses. The interaction between these two predictors of job satisfaction and its aspects however was not significant and did not contribute to the model, $p>.050$.

\section{RESULTS FROM STUDY 2}

\section{Descriptive statistics and correlational analyses}

Mean scores, standard deviations, reliabilities of measures and correlations between entitlement and organizational commitment are reported in Table 3. Based on the preliminary scatterplots, six outliers were identified and removed from the analyses.

Internal consistency reliability (Cronbach's $\alpha$ ) of the scales were at an acceptable level. Mean scores indicated that participants demonstrated a high level of active entitlement followed by the passive aspect of entitlement attitude. Inclination to revenge was less pronounced. The paired-sample $t$-test established that differences in the mean scores were statistically significant, $p<.001$. Employees felt moderately committed to their organizations, and this applied to all three aspects of commitment. The pattern of correlations did not completely support the assumed relationship. Hypothesis 4 was partially confirmed, because only passive entitlement correlated positively moderately and statistically significantly with instrumental commitment, whereas active entitlement and revengefulness were unrelated to instrumental attitude toward the company. As predicted by Hypothesis 5 , the correlation between revengefulness and affective commitment was negative. This relationship was weak, but statistically significant. Contrary to the expectation that active, passive and revenge entitlement should correlate negatively with normative commitment, the results showed that they were unrelated to this aspect of organizational commitment.

\section{Regression analyses}

In order to examine more complex interrelations between entitlement attitudes and affective, instrumental and normative forms of commitment, multiple hierarchical regression analyses were performed separately for each dimension of commitment. To control for demographic variables, data for age, gender, work experience, education level, work position and type of company were introduced to the regression model in the first step. In the second step, active, passive and revenge entitlement were introduced as predictors into the equation and the mean scores for the three dimensions of commitment as dependent variables. Table 4 presents the results from regression analyses.

Controlled demographic variables together explained $16.70 \%$ of variability in affective commitment. Affective commitment was predicted by higher job position in the first step, $F(6,81)=2.71, p=.019$. The addition of entitlement dimensions as predictors in step 2 increased the percent of variability in the dependent variable, accounting for $16.70 \%$ to $27.10 \%$. The change of $R^{2}$ was slight, but statistically significant, $F(3,78)=3.17, p=.015$. In step 2 managerial job position, private type of organization and low level of revenge entitlement predicted affective commitment, $F(9,78)=3.23, p=.002$. Emotional aspect of organizational commitment was unrelated to active and passive entitlement. The standardized $\beta$ value indicated that revengefulness had a slightly greater

Table 3

Internal consistency reliability (Cronbach's $\alpha$ ), means, standard deviations and intercorrelations among all variables in study $2(N=89)$

\begin{tabular}{|c|c|c|c|c|c|c|}
\hline Variables & 1 & 2 & 3 & 4 & 5 & 6 \\
\hline 1. Active entitlement & $(.79)$ & & & & & \\
\hline 2. Passive entitlement & $.33^{* *}$ & $(.73)$ & & & & \\
\hline 3. Revenge entitlement & .15 & .16 & $(.82)$ & & & \\
\hline 4. Affective commitment & .05 & -.03 & $-.21^{*}$ & $(.72)$ & & \\
\hline 5. Instrumental commitment & .12 & $.34^{* *}$ & .14 & $.21^{*}$ & $(.75)$ & \\
\hline 6. Normative commitment & .16 & .02 & -.11 & $.48^{* *}$ & .17 & $(.65)$ \\
\hline M & 5.12 & 4.65 & 3.17 & 3.23 & 3.11 & 3.19 \\
\hline$S D$ & 0.53 & 0.62 & 0.72 & 0.62 & 0.68 & 0.47 \\
\hline
\end{tabular}


Table 4

Summary of results of multiple hierarchical regression analyses for entitlement dimensions as predictors of organizational commitment $(N=89)$

\begin{tabular}{|c|c|c|c|}
\hline Models/variables & $\begin{array}{c}\text { Affective } \\
\text { commitment }\end{array}$ & $\begin{array}{l}\text { Instrumental } \\
\text { commitment }\end{array}$ & $\begin{array}{c}\text { Normative } \\
\text { commitment }\end{array}$ \\
\hline Model 1 & $\Delta R^{2}=.11^{*}$ & $\Delta R^{2}=.09^{*}$ & $\Delta R^{2}=.02$ \\
\hline Gender & -.09 & -.07 & -.08 \\
\hline Age & -.02 & .10 & .08 \\
\hline Education & .03 & $.29^{* *}(2.73)$ & .08 \\
\hline Tenure & .13 & .12 & -.06 \\
\hline Job position & $.29^{*}(2.53)$ & .08 & $.25^{*}(2.06)$ \\
\hline Org. type & .17 & .07 & -.08 \\
\hline Model 2 & $\Delta R^{2}=.19^{* *}$ & $\Delta R^{2}=.18^{* *}$ & $\Delta R^{2}=.05$ \\
\hline Gender & -.13 & -.04 & -.11 \\
\hline Age & .09 & .12 & .14 \\
\hline Education & .03 & $.25^{*}(2.47)$ & .07 \\
\hline Tenure & .04 & .12 & -.10 \\
\hline Job position & $.28^{*}(2.51)$ & .11 & $.24^{*}(2.03)$ \\
\hline Org. type & $.31^{*}(2.38)$ & .01 & -.03 \\
\hline Active entitlement & .11 & .01 & $.23^{*}(2.00)$ \\
\hline Passive entitlement & -.02 & $.33^{* *}(3.06)$ & -.01 \\
\hline Revengefulness & $-.36^{* *}(-3.24)$ & .10 & -.18 \\
\hline
\end{tabular}

Note. Entries are standardized regressions coefficients, T-ratios in parentheses.

${ }^{*} p<.05 .{ }^{* *} p<.01 .{ }^{* *} p<.001$.

impact in the model and made a higher contribution to affective commitment.

Instrumental commitment was predicted by educational level, as people with a lower level demonstrated a higher instrumental attitude toward their organizations, $F(6,81)=2.39, p=.035$. The model of controlled demographic variables accounted for $15 \%$ of the variance in instrumental commitment. Introducing the entitlement dimensions explained an additional $11.70 \%$ of the variation in instrumental commitment and increased the predictive power of the final model to $26.70 \%$ of the variability. The change in $R^{2}$ was statistically significant, $F(3,78)=4.12$, $p=.009$. Passive entitlement predicted positively instrumental commitment, $F(9,78)=3.15, p=.003$, whereas active and revenge entitlement were unrelated to it. So, only the passive form of entitlement is a predictor of instrumental commitment.

Neither the first model (demographic variables alone), $F(6,81)=1.26, p=.282$, nor the second model (including the three facets of entitlement), $F(6,81)=1.53, p=.153$, predicted scores in normative commitment to a statistically significant degree. Despite the lack of significance, an interesting tendency was observed in standardized coefficients - the $\beta$ value indicated that active entitlement might be positively related to normative commitment, $\beta=.23$, $p=.049, t=1.99$. This tendency should be evaluated again in the future with a bigger sample.

Again, as in study 1, the interaction between type of organization and entitlement dimensions, added in the third model, was nonsignificant, $p>.050$.

\section{DISCUSSION}

The current studies confirmed that entitlement attitudes are related to important workplace outcomes such as job satisfaction and organizational commitment, but their influence in an organizational context is not only negative and dysfunctional. These relationships were more complex than assumed, and they depend on the type of entitlement.

In study 1 , active entitlement was related to more aspects of job satisfaction and all correlations were positive. Thus, active entitlement seems to be a positive predictor of job satisfaction. It had a positive effect on satisfaction with results, satisfaction with supervisor, pay satisfaction and overall job satisfaction. Passive entitlement had a positive effect on 
satisfaction with tasks, but it had a negative effect on pay satisfaction. Revengefulness seems to be dysfunctional at work, because it was negatively related to task satisfaction, satisfaction with supervisor and overall satisfaction. Controlling for demographic characteristics allowed us to confirm the expected effect of entitlement attitudes as an essential predictor of job satisfaction. Although the predictive power of entitlement in this case was not high, since it explained from $10 \%$ to $18 \%$ of variability in the aspects of job satisfaction, it made a unique statistically significant contribution to the level of job satisfaction.

On the basis of the described results, one could conclude that in general the expected relationship and directions of correlations between entitlement dimensions and aspects of job satisfaction were established in this research though some of the hypotheses were not confirmed or were partially confirmed. For example, it was found that active entitlement was positively related to satisfaction with supervisor and pay satisfaction. In the case of active entitlement, self-promotion and self-assertion dominate, which may result in overestimation of one's own inputs and subsequently in a feeling of insufficient appreciation by the employer. On the basis of this assumption it was predicted that people with high active entitlement would be less satisfied with pay and would have a negative attitude to their boss. The revealed positive relationship between active entitlement and both aspects of job satisfaction might be mediated by other variables such as subjective well-being, personal values and aspirations, social desirability or some job characteristics. A recent study by Laird et al. (2015) observed that the impact of entitlement on job dissatisfaction was largely neutralized when high accountability levels were present.

Another possible interpretation could stem from the qualitative model of different forms of job satisfaction devised by Bruggemann (1974) and further developed by Büssing (1992). Development of job satisfaction is a result of four core processes: comparison of the present work situation to personal aspiration; readjustment or maintenance of the level of aspiration; problem solving, problem fixation, i.e. preoccupation with the problem suppression in cases of dissatisfaction (Bruggemann, 1974, cited by Unterrainer, Jeppesen, \& Jønsson, 2013); and perceived controllability at work (Büssing, 1992; Inauen, Jenny, $\&$ Bauer, 2015). Given that active entitled employees are assertive and self-confident, they may tend to maintain the level of aspiration even in unsolvable negative working conditions, which can result in so-called pseudo job satisfaction. This type of satisfaction is based on ego-protective mechanisms that lead to distorted perception or denial of the negative work situation. Employees with high active entitlement are not only assertive, but they are also proactive and goal-oriented, which means that in cases of indistinct dissatisfaction they tend to stick to their aspiration level and search for new solutions to their actual job problems. The result is constructive job satisfaction (Büssing, 1992). So, in an attempt to protect their high self-esteem and sense of self-worth, people with active entitlement may tend to develop these two types of job satisfaction. This model could provide a possible explanation of the positive relationship of active entitlement with satisfaction with supervisor and pay.

According to the model there is a passive form of satisfaction, called by Bruggemann (1974) 'resigned satisfaction'. It occurs when employees feel indistinct work dissatisfaction and decrease their level of aspiration in order to adapt to negative aspects of the work situation. By decreasing their level of aspiration, people are able to achieve a state of satisfaction again (Inauen et al., 2015). The positive relationship between passive entitlement and satisfaction with tasks could be interpreted as resigned satisfaction. Since people with passive entitlement have lower self-esteem and external locus of control, for them it might be easier to decrease their level of aspirations when they are not congruent with the present work situation and job characteristics. In this way, resigned satisfaction plays the role of an ego-protective mechanism and provides entitled employees a source of positive emotions facilitating their functioning at work. So, employees with active and passive entitlement may use a similar ego-protective mechanism but they differ in their motives to do this. For people with active entitlement it is important to experience a state of satisfaction at work and to feel successful, while people with passive entitlement try to reduce the state of dissatisfaction and additional efforts it takes.

The positive influence of active entitlement on satisfaction with own work results and overall satisfaction is also consistent with the results of a study conducted by Brummel and Parker (2015), according to which entitlement was related to higher self-rated task performance and to fewer self-reported counterproductive working behaviors. The results of study 1 indicated that passive entitlement was negatively related to pay satisfaction. Employees with high passive entitlement, who believe that other people and institutions have certain obligations toward them, may develop higher expectations toward their employers, considering that they are obliged to provide them with a high salary and rewards regardless of their merits. In general, people with passive entitlement are less active and self-assertive and focused mainly on receiving rather than on giving. This type of behavior in turn does not allow them to be promoted, and as a result they are likely to perceive a greater discrepancy between entitlements promised and those received from the organization. Passive entitlement was unrelated to overall job satisfaction and other aspects of this attitude. 
Expected negative effects of revengefulness on job satisfaction are confirmed and are completely in line with its conceptualization and other research. Revengeful employees tend to respond negatively when the present work situation does not meet their expectations. Experienced frustration and deprivation provoke them to develop a negative attitude toward the job and workplace.

The results from study 2 confirmed that entitlement dimensions play a role in predicting organizational commitment. Again, as in study 1, different forms of entitlement had a diverse influence on the various components of organizational commitment. Revengefulness had a negative effect on affective commitment, which confirmed hypothesis 5 . Revengeful employees have difficulty in maintaining good social relationships, because they cannot forgive criticism, unfulfilled promises or wrongs, perceiving them as deliberate insults. This attitude hinders their relationship with the organization and prevents them from developing an emotional attachment to the company and to feel as a part of it. Higher level of passive entitlement predicted instrumental commitment. Employees with high passive entitlement are unwilling to fight actively for their goals and to search for different options, considering that the organization is obliged to take care of them. Therefore, they are emotionally reserved toward the organization, but continue to work there because of the personal benefit and the perceived lack of alternatives. So, passive entitlement promotes a more rational relationship between employees and the organization. Active and revenge entitlement were unrelated to instrumental commitment. Normative commitment was not predicted by any of the entitlement types. Unexpectedly however, though statistically insignificant, there was a tendency to a positive weak relationship between active entitlement and normative commitment. Given that people with active entitlement have inflated self-esteem and are goal oriented, they may start to perceive themselves as extremely valuable and irreplaceable for the organization. From this point of view, to remain in the company would be a matter of honor for them.

\section{CONCLUSIONS}

On the basis of the described results, it can be concluded that the entitlement attitude as a multidimensional phenomenon is relevant to the workplace and can predict to some extent job satisfaction and organizational commitment. Different forms of entitlement - active, passive and revenge entitlement have a diverse influence on the various aspects of job satisfaction and components of organizational commitment. Active and passive types of entitlement are more adaptive, whereas revengefulness is a maladaptive and dysfunctional attitude. These results may have practical application in human resource management, because they raise the question how organizations can prevent or reduce over-entitlement or revengefulness and stimulate active entitlement of their employees. First, organizations can take care to manage employees' expectations by appropriate human resource practices during the recruitment and socialization processes. For example, providing realistic job previews that clearly describe job aspects, responsibilities, obligations and due privileges will make employees feel well informed and will develop their legitimate entitlement. At the same time, as certain types of entitlement, such as active, may be associated with characteristics desirable to the workplace, such as agency, initiative and assertiveness, while others are maladaptive, entitlement beliefs could be used as a screening tool for selection, but only on the basis of more nuanced measurement. Second, the organization has to clarify the relationship between employees' inputs, performance levels and possible rewards. Through open communication, honest discussion of mutual obligations, regular performance feedback and adequate explanations, managers may ensure lucidity and predictability. This will provide distributive, procedural and interactional justice that can regulate employees' expectations and entitlement beliefs and would minimize the perceptions of psychological contract violation. Finally, a reward system based on a "pay-for-performance philosophy" instead of seniority, tenure or status may encourage various organizational rewards to be regarded as a matter of deservingness, not entitlement.

\section{RefERENCES}

Adams, J. S. (1965). Inequity in social exchange. In L. Berkowitz (ed.), Advances in experimental social psychology (pp. 267-299). New York: Academic Press Inc.

Allen, N., \& Meyer, J. (1990). The measurement and antecedents of affective, continuance and normative commitment to the organization. Journal of Occupational Psychology, 63, 1-18.

Ashforth, B. E., \& Saks, A. M. (2000). Personal control in organizations: A longitudinal investigation with newcomers. Human Relations, 53, 311-339.

Bruggemann, A. (1974). Zur Unterscheidung verschiedener Formen von "Arbeitszufriedenheit" [On different forms of job satisfaction]. Arbeit und Leistung, 28, 281-284.

Brummel, B., \& Parker, K. (2015). Obligation and Entitlement in Society and the Workplace. Applied Psychology: An International Review, 64, 127-160.

Büssing, A. (1992). A dynamic view of job satisfaction in psychiatric nurses in Germany. Work 
\& Stress, 6, 239-259. doi: http://dx.doi.org/10.1080/ 02678379208259956

Byrne, Z., Miller, B., \& Pitts, V. (2010). Trait entitlement and perceived favorability of human resource management practices in the prediction of job satisfaction. Journal of Business and Psychology, 25, 451-464.

Campbell,W. K., Bonacci, A. M., Shelton, J., Exline, J. J., \& Bushman, B. J. (2004). Psychological entitlement: Interpersonal consequences and validation of a self-report measure. Journal of Personality Assessment, 83, 29-45.

Fisher, C. D. (2000). Mood and emotions while working: Missing pieces of job satisfaction? Journal of Organizational Behavior, 21, 185-202.

Fisk, G. (2010). "I want it all and I want it now!" An examination of the etiology, expression, and escalation of excessive employee entitlement. Human Resource Management Review, 20, 102-114.

Harvey, P., \& Dasborough, M. (2015). Entitled to solutions: The need for research on workplace entitlement. Journal of Organizational Behavior, 36, 460-465.

Harvey, P., \& Harris, K. J. (2010). Frustration-based outcomes of entitlement and influence of supervisor communication. Human Relations, 63, 16391660.

Harvey, P., \& Martinko, M. J. (2009). An empirical examination of the role of attributions in psychological entitlement and its outcomes. Journal of Organizational Behavior, 30, 459-476.

Huseman, R. C., Hatfield, J. D., \& Miles, E. W. (1987). A new perspective on equity theory: the equity sensitivity construct. Academy of Management Review, 12, 222-234.

Ilieva, S. (1998). Привързаност към организацията. Психологически анализ [Organizational commitment. Psychological analysis]. С., “Албатрос".

Inauen, A., Jenny, G. J., \& Bauer, G. F. (2015). Discriminating five forms of job satisfaction: Investigating their relevance for occupational health research and practice. Psychology, 6, 138-150.

Knights, J., \& Kennedy, B. (2005). Psychological contract violation: Impacts on job satisfaction and organizational commitment among Australian senior public servants. Applied HRM Research, 10, $57-72$.

Laird, M., Harvey, P., \& Lancaster, J. (2015). Accountability, entitlement, tenure, and satisfaction in Generation Y. Journal of Managerial Psychology, 30, 87-100.

Major, D. A., Kozlowski, S. W. J., Chao, G. T., \& Gardner, P. D. (1995). A longitudinal investigation of newcomer expectations, early socialization outcomes, and the moderating effects of role development factors. Journal of Applied Psychology, 80, 418-431.
Martinko, M. J., \& Gardner, W. L. (1987). The leader member attribution process. Academy of Management Review, 72, 235-249.

Naumann, S., Minsky, B., \& Sturman, M. (2002). The use of the concept 'entitlement' in management literature: a historical review, synthesis, and discussion of compensation policy implications. $\mathrm{Hu}$ man Resource Management Review, 12, 145-166.

Paspalanova, E., \& Dragova, S. (2013). Факторна структура на въпросник за измерване на нагласата „Полага ми се" [Factor structure of Entitlement questionnaire]. Психологични изследвания, 2, 307-312.

Piotrowski, J., \& Żemojtel-Piotrowska, M. (2009). Kwestionariusz roszczeniowości [Entitlement questionnaire]. Roczniki Psychologiczne, 12, 151-177.

Radoslavova, M., \& Velichkov, A. (2005). Методи за психодиагностика [Methods for psychological diagnostics]. Sofia: Andora Prim.

Raskin, R., \& Terry, H. (1988). A principal-components analysis of the Narcissistic Personality Inventory and further evidence of its construct validity. Journal of Personality and Social Psychology, 54, 890-902.

Sauley, K. S., \& Bedeian, A. G. (2000). Equity sensitivity: construction of a measure and examination of its psychometric properties. Journal of Management, 26, 885-910.

Tomlinson, E. (2013). An Integrative Model of Entitlement Beliefs. Employee Responsibilities and Rights Journal, 25, 67-87.

Twenge, J. M. (2006). Generation Me-Revised and Updated: Why today's young Americans are more confident, assertive, entitled and more miserable than ever before. New York: Free Press.

Unterrainer, C., Jeppesen, H., \& Jønsson, T. (2013). Different forms of job satisfaction: Does job satisfaction means satisfied employees? Psyke \& Logos, 34, 398-419.

Wanous, J. P., Poland, T. D., Premack, S. L., \& Davis, K. S. (1992). The effects of met expectations on newcomer attitudes and behaviors: a review and meta-analysis. Journal of Applied Psychology, 77, 288-297.

Wolfe Morrison, E., \& Robinson, S. L. (1997). When employees feel betrayed: a model of how psychological contract violation develops. Academy of Management Review, 22, 226-231.

Żemojtel-Piotrowska, M., Baran, T., Clinton, A., Piotrowski, J., Baltatescu, S., \& Van Hiel, A. (2013). Materialism, subjective well-being, and entitlement. Journal of Social Research and Policy, 4, 79-91.

Żemojtel-Piotrowska, M., \& Piotrowski, J. (2012). Entitlement and belief in zero-sum game in the organizational context. In M. Lipowski \& Z. Nieckarz (Eds.), Management psychology in contemporary research (pp. 396-432). Gdańsk: WSA \& B. 